\title{
Pharmacovigilance: Empowering Healthcare Professionals
}

\author{
Snežana S. Mugoša, Maja V. Stanković, Nemanja M. Turković, \\ Željka M. Bešović, Majda M. Šahman - Zaimović, Milorad D. Drljević
}

Agency for Medicines and Medical Devices of Montenegro, Podgorica, Montenegro

\section{SUMMARY}

Introduction: Spontaneous reporting of adverse reactions is of greatest importance for obtaining information about adverse drug reactions (ADRs) after granting the marketing authorization. The most important role and also the greatest responsibility belong to healthcare professionals. Their active participation is a prerequisite for the existence of an effective national drug safety monitoring.

Methods: This paper examines the legislative framework concerning the pharmacovigilance system in Montenegro. The information was collected from scientific articles and the website of the Agency for Medicines and Medical Devices of Montenegro.

Topic: Key segments of pharmacovigilance system are presented, with a special reference to the importance of spontaneous reporting of ADRs, results of spontaneous reporting of ADRs according to the latest Agency's Annual report on the results of spontaneous reporting of adverse reactions to medicines, possible reasons for underreporting ADRs, as well as the new EU regulation on pharmacovigilance.

Conclusions: Spontaneous reporting of ADRs remains the cornerstone of pharmacovigilance systems. Hence, continuous education of healthcare professionals is needed, with the aim of improving their awareness of the importance of ADRs and risk factors that lead to them, in order to reduce the incidence of ADRs and to increase the number of reported suspected ADRs.

Keywords: adverse drug reaction, drug safety, pharmacovigilance

\section{INTRODUCTION}

According to the definition of World Health Organization (WHO), pharmacovigilance is a science that comprises activities relating to the detection, assessment, understanding and prevention of adverse effects or any other possible drug-related problem [1]. The specific aims of pharmacovigilance are to: improve patient care and safety in relation to the use of medicines and all medical and paramedical interventions, improve public health and safety in relation to the use of medicines, contribute to the assessment of benefit, harm, effectiveness and risk of medicines, encouraging their safe, rational and more effective (including costeffective) use, and promote understanding, education and clinical training in pharmacovigilance and its effective communication to the public [2].

Adverse drug reactions (ADRs) are observed during the preclinical and clinical trials. Data collected during these phases of drug development cannot predict the possible ADRs that may manifest only after placing the medicinal product on the market. The reasons are different. For example, animal studies are insufficient to predict the safety of the medi- 
cines in humans; limited number of selected patients is included in clinical trials, conditions of administration of medicine are different from those in normal clinical practice, and duration of trials is limited; only ADRs with higher incidence of manifestation could have been observed because less than 5000 patients would be exposed to medicine during clinical trials before its placing on the market; data on rare serious adverse events, toxic effects of chronic treatment, use of the medicine in specific categories of patients (children, the elderly, pregnant women) or interactions with other medicines are often incomplete or not available [3].

Pharmacovigilance is the need and obligation of every country, because there are differences in the incidence of ADRs (and other problems caused by medicines) among different communities. Causes may be as follows: differences in prevalence of certain diseases; genetic factors, diet, habits; different practice of prescribing medicines; different manufacturing process (using different excipients, diluents, fillers, preservatives, antioxidants...) which affects the quality and composition of medicines; differences in the use of the drug, including the therapeutic indication and the dosage regimen; co-administration of the traditional and herbal products which may cause specific toxicological problems, whether administered alone or in combination with other medicines [4].

Therefore, post-marketing surveillance activities are important to allow the early detection of unexpected and/or serious adverse reactions. Important part of post-marketing surveillance is also related to detection of falsified medicines.

\section{METHODS}

This paper examines the legislative framework concerning the pharmacovigilance system in Montenegro. The information was collected from scientific articles and the website of the Agency for Medicines and Medical Devices of Montenegro.

\section{TOPIC}

\section{Importance of spontaneous reporting of ADRs}

ADRs appear more frequently then what is actually reported and registered. According to the information that literature has provided, it has been estimated that $10-30 \%$ of hospitalized patients experience ADRs [5-9] and 0.3-10\% of all hospital admissions are actually results of ADRs [10-12]. In hospital environment, 3\% of all fatal outcomes are caused by ADRs [7]. ADRs also cause prolongation of the hospitalization period and increase of hospital costs [6]. It is estimated that only $6-10 \%$ of all ADRs are reported: This underestimation is a major problem [13]. Although the extent of underreporting is widely variable depending on the estimates, it is certain that the number of reported ADRs represents only a small percentage of the total number of occurring ADRs [14].

In consideration of aforementioned, spontaneous reporting of adverse reactions is of greatest importance for obtaining information about adverse drug reactions (ADRs) after granting the marketing authorization.

The most important role and also the greatest responsibility belong to healthcare professionals. Their active participation is a prerequisite for the existence of an effective national drug safety monitoring.

Reporting of adverse drug reactions is a legal obligation [15] for all healthcare professionals in Montenegro prescribing, issuing and handling drugs in clinical practice. It is very important to involve all, physicians as prescribers, pharmacists as experts in medicines, the last control of prescribers, healthcare professional who is the most important link between prescribers and patients, and finally the nurses involved and responsible for the proper preparation and administration of certain drugs. The Agency for Medicines and Medical Devices of Montenegro (CALIMS), as a full member of the WHO, in order to protect public health by monitoring the safety of medicines, collects, assesses and manages all reported suspected ADRs into a national database, and forwards them to the Uppsala Monitoring Centre.

\section{Pharmacovigilance in Europe}

The trigger for proposal, final approval by the European Parliament and entry into the force of the new EU regulation on pharmacovigilance was appalling statistics at the level of EU countries, in which the pharmacovigilance system was building through decades, especially when 
it comes to proven fatalities caused by irrational use of medicines (200 000 deaths annually in the EU due to adverse effects of medicines) [16] and the enormous costs of their treatment (about 709 billion euros annually) [16-18].

On July 21, 2012, a new EU pharmacovigilance legislation came into force in order to strengthen and rationalize the EU pharmacovigilance system, with the overall objectives of better protection of public health, ensuring proper functioning of the internal market and simplifying the existing procedures [19].

At European level, government agencies responsible for pharmacovigilance in Member States are in contact with each other and with the European Medicines Agency (EMA) [20]. EudraVigilance - a web-based European network has been established by EMA, for reporting and exchanging suspected ADRs reports, during the pre-authorization phase and following post-authorization phase of medicinal products in the European Economic Area. EudraVigilance is an European database, which supports: [21]

1 . The early detection of possible safety signals associated with medicinal products for human use.

2. The continual monitoring and evaluation of potential safety issues in relation to reported adverse reactions. The decision making process, based on a broader knowledge of the adverse reaction profile of medicinal products.

\section{Pharmacovigilance in Montenegro}

Fulfilled reporting form could be submitted to the Agency in one of the following manners: by post, in person, by fax or by e-mail [22]. In 2013 the possibility of reporting through the information system of primary healthcare institutions and general hospitals was introduced. This is expected to be the principal method when it comes to report ADRs, because it is an easy, safe and fast way to transfer date from a healthcare institution to CALIMS. Results of spontaneous reporting of ADRs, according to the latest CALIMS annual report [23], indicate that the number of reports per million inhabitants is 156. That number is under recommendation of the World Health Organization of 200 reports per million inhabitants [24].

The largest number of reports, according to the ATC classification of suspected drugs, related to drugs belonging to the group of antineoplastics and immunomodulators, and anti-infective drugs for systemic use [23]. While in the EU and in many countries around the world, to the appropriate agency quality reports are sent by patients, which are often the reason for the adoption of measures by the competent authorities, in Montenegro, unfortunately, we cannot yet speak of a developed awareness among healthcare professionals about the importance of reporting adverse drug reactions, primarily to public health, and further the economic viability of the healthcare system.

A huge responsibility is on the national agencies and manufacturers of medicines, but the most important role and responsibility for the health of people is on healthcare professionals. The lack of appropriate statistics in Montenegro on adverse effects, in terms of treatment outcomes and financial burden caused by their treatment does not mean that we as a country spared this, in today's conditions of global phenomena. Agency for Medicines and Medical Devices of Montenegro (CALIMS) recognized as a challenge to raise awareness of healthcare professionals about the importance of pharmacovigilance and development of this scientific discipline, through continuing education. Aware of its responsibility for the public health, CALIMS continues the education in the field of pharmacovigilance. One of them is organizing workshops on pharmacovigilance for the development of a system for continuous monitoring of safety of medicines.

\section{Possible reasons for not reporting ADRs}

In prospective study conducted by the author, which included 200 patients, hospitalized at Cardiology Centre of the Clinical Centre of Montenegro last year, results showed that 34\% of all patients experienced at least one ADRs. Considering high incidence of ADRs in our study and the fact that none observed suspicion of ADRs wasn't reported to the CALIMS by health workers, it can be concluded that in Montenegro system of spontaneous reporting of ADRs does not provide enough information about the safety drugs use.

It is possible that doctors and nurses don't report ADRs due to: preoccupation with everyday duties and otherwise oversized ad- 
ministrative work they do, the lack of increased spontaneous reporting system, focusing on ADRs patients have had during hospitalization, with lower paying attention to ADRs that caused hospitalization, reluctance to report ADRs which were preventable, guilt incurred for ADRs, lack of motivation, etc.

\section{CONCLUSION}

National ADRs reporting system in Montenegro is organized by the Pharmacovigilance Department of the Agency for Medicines and Medical Devices of Montenegro. Number of reports coming from healthcare professionals is quite low [23].

For HCPs, the emphasis should be on education and training, both at the undergraduate and graduate level, to recognize ADRs and knowing what, how and where to report them, e.g. by practicing how to fill out a Report form. Healthcare professionals also have to stay informed about changing regulations and evolving procedures and/or techniques. Hence, continuous education of healthcare professionals is needed, with the aim of improving their awareness of the importance of ADRs and the risk factors that lead to them, in order to reduce the incidence of ADRs and to increase the number of reported suspected ADRs.

\section{REFERENCES}

1. The IMPORTANCE of PHARMACOVIGILANCE. Safety Monitoring of medicinal products [Internet]. WHO. 2002 [cited 2014 Sep 26]. Available from: http:// apps.who.int/medicinedocs/pdf/s4893e/s4893e. pdf

2. Düsing R. Overcoming barriers to effective blood pressure control in patients with hypertension. Curr Med Res Opin. 2006;22:1545-53.

3. JelenkovićA. Neželjena dejstva ljekova. Beograd: Hellen J; 2002.

4. Safety of Medicines - A Guide to Detecting and Reporting Adverse Drug Reactions - Why Health Professionals Need to Take Action: Why pharmacovigilance is needed in every country [Internet]. [cited 2015 Mar 27]. Available from: http://apps.who.int/ medicinedocs/en/d/Jh2992e/5.html

5. Dormann H, Muth-Selbach U, Krebs S, CriegeeRieck M, Tegeder I, Schneider HT, et al. Incidence and costs of adverse drug reactions during hospitalisation: computerised monitoring versus stimulated spontaneous reporting. Drug Saf. 2000;22:161-8.

6. Bates DW, Leape LL, Petrycki S. Incidence and preventability of adverse drug events in hospitalized adults. J Gen Intern Med. 1993;8:289-94.

7. Smith CC, Bennett PM, Pearce HM, Harrison PI, Reynolds DJ, Aronson JK, et al. Adverse drug reactions in a hospital general medical unit meriting notification to the Committee on Safety of Medicines. Br J Clin Pharmacol. 1996;42:423-9.

8. Varenhorst $C$, James S, Erlinge D, Brandt JT, Braun 00, Man M, et al. Genetic variation of CYP2C19 affects both pharmacokinetic and pharmacodynamic responses to clopidogrel but not prasugrel in aspirin-treated patients with coronary artery disease. Eur Heart J [Internet]. 2009 [cited 2014 Sep 26];30(14):1744-52. Available from: http://www. pubmedcentral.nih.gov/articlerender.fcgi?artid=27 09885\&tool=pmcentrez\&rendertype=abstract

9. Johnson JA, Bootman JL. Drug-related morbidity and mortality. A cost-of-illness model. Arch Intern Med. 1995;155:1949-56.

10. Hallas J, Harvald B, Gram LF, Grodum E, Brøsen $K$, Haghfelt T, et al. Drug related hospital admissions: the role of definitions and intensity of data collection, and the possibility of prevention. J Intern Med [Internet]. 1990 [cited 2014 Sep 27];228(2):8390. Available from: http://www.ncbi.nlm.nih.gov/ pubmed/2394974

11. Impicciatore $P$, Choonara I, Clarkson A, Provasi $D$, Pandolfini C, Bonati M. Incidence of adverse drug reactions in paediatric in/out-patients: a systematic review and meta-analysis of prospective studies. Br J Clin Pharmacol [Internet]. 2001 [cited 2014 Sep 26];52(1):77-83. Available from: http://www. pubmedcentral.nih.gov/articlerender.fcgi?artid=20 14499\&tool=pmcentrez\&rendertype=abstract

12. Peyriere H, Cassan S, Floutard E, Riviere S, Blayac J-P, Hillaire-Buys $D$, et al. Adverse drug events associated with hospital admission. Ann Pharmacother [Internet]. 2003 [cited 2014 Sep 27];37(1):511. Available from: http://www.ncbi.nlm.nih.gov/ pubmed/12503925

13. Mazzitello C, Esposito S, De Francesco AE, Capuano A, Russo E, De Sarro G. Pharmacovigilance in Italy: An overview. J Pharmacol Pharmacother [Internet]. 2013 [cited 2014 Dec 29];4(Suppl 1):S20-8. Available from: http://www.pubmedcentral.nih. gov/articlerender. fcgi?artid=3853663\&tool=pmcent rez\&rendertype=abstract

14. Rawlins MD. Spontaneous reporting of adverse drug reactions. I: the data. Br J Clin Pharmacol [Internet]. 1988 [cited 2015 May 11];26(1):1-5. Available from: http://www.pubmedcentral.nih.gov/ articlerender. fcgi? artid=1386492\&tool=pmcentrez\& rendertype $=$ abstract

15. Službeni list Crne Gore - Propis - Zakon o ljekovima [Internet]. [cited 2014 Sep 26]. Available from: http://www.sluzbenilist.me/PravniAktDetalji.aspx?tag $=\{$ EB8D380A-167D-4B1B-BFBBB6593034D628\}

16. Setting the scene new European Union Phar- 
macovigilance legislation-P Arlett - WC500137839. pdf [Internet]. [cited 2015 Mar 27]. Available from: http://www.ema.europa.eu/docs/en_ GB/document_library/Presentation/2013/01/ WC500137839.pdf

17. Capuano A, Irpino A, Gallo M, Ferrante L, Illiano $M L$, Rinaldi $B$, et al. Regional surveillance of emergency-department visits for outpatient adverse drug events. Eur J Clin Pharmacol [Internet]. 2009 [cited 2015 May 11];65(7):721-8. Available from: http://www.ncbi.nlm.nih.gov/pubmed/19294371

18. Capuano A, Motola G, Russo F, Avolio A, Filippelli $A$, Rossi $F$, et al. Adverse drug events in two emergency departments in Naples, Italy: an observational study. Pharmacol Res [Internet]. 2004 [cited 2015 May 11];50(6):631-6. Available from: http://www. ncbi.nlm.nih.gov/pubmed/15501703

19. European Medicines Agency - Pharmacovigilance - Pharmacovigilance legislation [Internet]. [cited 2015 May 11]. Available from: http://www. ema.europa.eu/ema/index.jsp?curl=pages/special_topics/general/general_content_000491. jsp\&mid=WCOb01ac058058f32d

20. Directive 2010/84/EU of the European Parliament and of the Council of 15 December 2010 amending, as regards pharmacovigilance, Directive $2001 / 83$ /EC on the Community code relating to medicinal products for human useText with EEA relevance - dir_2010_84_en. [Internet]. [cited 2014 Sep 26]. Available from: http://ec.europa.eu/health/ files/eudralex/vol-1/dir_2010_84/dir_2010_84_ en.pdf

21. EudraVigilance - Pharmacovigilance in EEA [Internet]. [cited 2015 May 11]. Available from: http:/ / eudravigilance.ema.europa.eu/human/index.asp

22. How to report an adverse reactions to medicines [Internet]. [cited 2015 May 11]. Available from: http://www.calims.me/Portal/faces/dinamickeStrane?_afrLoop=13862279849880099\&par amPut $=+>+$ Pharmacovigilance $+>+$ How + to + report + a $\mathrm{n}+$ adverse+reactions+to+medicines\&paramRender= 2\&paramS=53\&_adf.ctrl-state=a06ty6g6h_82

23. Izvještaj Agencije za ljekove i medicinska sredstva Crne Gore o prijavama neželjenih dejstava ljekova za 2013. godinu [Internet]. [cited $2014 \mathrm{Sep}$ 26]. Available from: http://www.calims.me/Portal/faces/servlet1?putanja=Izvjestaj+o+prijavljeni $\mathrm{m}+$ nezeljenim+dejstvima+za+2013.+godinu.pdf\&_ afrWindowMode=0\&_afrLoop $=16928125648407 \&$ _ adf.ctrl-state=1mif24tdl_91

24. Reporting_Guidelines.pdf [Internet]. [cited 2015 May 11]. Available from: http: / /www.who.int/ patientsafety/events/05/Reporting_Guidelines.pdf 


\section{Farmakovigilanca: podsticaj zdravstvenim radnicima}

Snežana S. Mugoša, Maja V. Stanković, Nemanja M. Turković, Željka M. Bešović, Majda M. Šahman - Zaimović, Milorad D. Drljević

Agencija za ljekove i medicinska sredstva Crne Gore, Podgorica, Crna Gora

\section{KRATAK SADRŽAJ}

Uvod: Najveći značaj u prikupljanju informacija o neželjenim dejstvima lekova nakon dobijanja dozvole za stavljanje u promet ima spontano prijavljivanje neželjenih dejstava. Najznačajnija uloga, ujedno i najveća odgovornost, pripada zdravstvenim radnicima. Njihovo aktivno učešće je preduslov postojanja efikasnog nacionalnog sistema nadzora nad bezbednom primenom lekova.

Metodologija: $U$ ovom radu objašnjen je regulatorni okvir u sistemu farmakovigilance u Crnoj Gori. Informacije su prikupljene iz literature i sa portala Agencije za ljekove i medicinska sredstva Crne Gore.

Tema: Prikazani su ključni segmenti u sistemu farmakovigilance, sa posebnim osvrtom na značaj prijavljivanja neželjenih dejstava lekova, rezultati poslednjeg godišnjeg Izveštaja Agencije o rezultatima prijavljivanja neželjenih dejstava lekova, mogući razlozi za neprijavljivanje neželjenih dejstava lekova, kao i nova evropska regulativa u oblasti farmakovigilance.

Zaključci: Spontano prijavljivanje neželjenih dejstava lekova je kamen temeljac sistema farmakovigilance. Stoga je potrebna kontinuirana edukacija zdravstvenih radnika, s ciljem unapređenja njihove informisanosti o značaju neželjenih dejstava lekova i faktora rizika koji do njih dovode, kako bi se njihova učestalost ispoljavanja smanjila, a broj prijavljenih sumnji na neželjena dejstva povećao.

Ključne reči: neželjena dejstva lekova, bezbedna primena lekova, farmakovigilanca 